\title{
Edible Insects and Sustainable Development Goals
}

\author{
Roberta Moruzzo $^{1}\left(\mathbb{D}\right.$, Simone Mancini ${ }^{1,2, *(D)}$ and Alessandra Guidi ${ }^{1,2}$ (D) \\ 1 Department of Veterinary Sciences, University of Pisa, Viale delle Piagge 2, 56124 Pisa, Italy; \\ roberta.moruzzo@unipi.it (R.M.); alessandra.guidi@unipi.it (A.G.) \\ 2 Interdepartmental Research Center "Nutraceuticals and Food for Health", University of Pisa, \\ Via del Borghetto 80, 56124 Pisa, Italy \\ * Correspondence: simone.mancini@unipi.it; Tel.: +39-050-2216-803
}

check for

updates

Citation: Moruzzo, R.; Mancini, S. Guidi, A. Edible Insects and Sustainable Development Goals. Insects 2021, 12, 557. https://doi.org/ $10.3390 /$ insects 12060557

Academic Editor: Takeshi Miura

Received: 20 April 2021

Accepted: 11 June 2021

Published: 15 June 2021

Publisher's Note: MDPI stays neutral with regard to jurisdictional claims in published maps and institutional affiliations.

Copyright: (c) 2021 by the authors. Licensee MDPI, Basel, Switzerland. This article is an open access article distributed under the terms and conditions of the Creative Commons Attribution (CC BY) license (https:// creativecommons.org/licenses/by/ $4.0 /)$.
Simple Summary: The United Nations Sustainable Development Goals (SDGs), seventeen urgent topics of action by all country, aim to reach ambitious and hopefully targets, such as peace and prosperity for people and the planet, now and into the future. Edible insects were individuated as a potential response to one of the major challenges of our times: increasing food production while decreasing environmental impact. In this review, the "insect idea" was linked to the single SDGs in order to express its potentiality. Likewise, indirect linking between insect farming and several SDGs was reported.

\begin{abstract}
The insect sector can become an important component of sustainable circular agriculture by closing nutrient and energy cycles, fostering food security, and minimising climate change and biodiversity loss, thereby contributing to SDGs. The high levels of the interaction of the insect sector with the SDGs is clearly illustrated inside the review, analysing all of the SDGs that can have direct and indirect effects on insects. Mapping the interactions between the SDGs goals and insect sector offers a starting point, from which it could be possible to define practical next steps for better insect policy.
\end{abstract}

Keywords: insect farming; SDGs; hunger; security; sustainability

\section{Introduction}

In the global sustainable development agenda, the United Nations' (UN) "Transforming Our World: The 2030 Agenda for Sustainable Development" adopted 17 Sustainable Development Goals (SDGs) that are intended to "stimulate action over the next 15 years in areas of critical importance for humanity and the planet". In policy circles, these SDGs are being increasingly referred to simply as "The Global Goals" [1]. They represent a global agreement across United Nation's member states "used in national development plans, academic and foreign aid prioritization" [2]. As reported by Waage et al. [3], the 17 SDGs, with 169 targets and 232 specific indicators, can be represented in three concentric layers, which reflect their main intended outcomes: the wellbeing goals (i.e., 1, 3, 4, 5, 10, 16 SDGs), the infrastructure goals (i.e., 2, 6, 7, 8, 9, 11, 12 SDGs), and the natural environment goals (i.e., 13, 14, 15 SDGs). According to the FAO, food production will have to increase by $70 \%$ to be able to feed the world in 2050; growing population, increasing wealth, and urbanization, especially in recent industrialized countries, have changed consumption patterns and food preferences, leading to higher animal protein demands. This context places heavy pressure on already limited resources, aggravates the competition for land to produce food, feed, and fuel, and makes the challenge of environmental sustainability even more difficult. Conversely, while one-third of food is wasted [4], 8.9\% of the world population are estimated to have been undernourished and $25.9 \%$ suffered from both moderate and severe levels of food insecurity in 2019. Insects reduce the above-mentioned societal challenges, create healthier and more sustainable food, and reduce animal feed 
production and consumption. Insects are rich in proteins (37-63\%) and fats (20-40\%), with well-balanced amino acid and fatty acid profiles, respectively, and they are good sources of minerals and vitamins [5]. When compared to conventional livestock, insect' production has a lower environmental impact because of, amongst other things, the limited need for land and water and the reduction in greenhouse gas and carbon dioxide emissions [6,7]. As poikilotherm, insects have a high feed conversion rate, requiring much less feed to produce the same amount of animal proteins: $1 \mathrm{~kg}$ of live animal weight of crickets requires $1.7 \mathrm{~kg}$ of feed, as compared to $2.5 \mathrm{~kg}$ for chicken, $5 \mathrm{~kg}$ for pork, and $10 \mathrm{~kg}$ for beef [8,9]. In addition, insects have a higher percentage of edible mass, up to $80 \%$ when compared to around $55 \%$ of chicken, $70 \%$ of pork, and only $40 \%$ of cattle. Insects can also be cultured on locally available industrial and agricultural waste streams, recycling a loss into a valuable protein source. Moreover, insects can be gathered from nature or farmed with simple techniques and minimal facilities requiring minimal land or capital and have a quick growth rate [5].

All of the above-mentioned insect features point out the high potentiality of this emerging sector. Insect farming will surely increase the overall agricultural production, both via large- and small-scale farms. An increased and widespread consciousness regarding the potential of insects will also contribute to political and marketing choices, contributing to increase livelihood, economic development, and social integration, especially in countries with a long tradition of entomophagy and insects rearing, such as Asia, South America, and Africa. A practical example of the insect potential is represented by the one called "The Thai example". Indeed, even if the use of insect as food was historically present in the country, in the last decades it was only improved by moving from collecting insects into the wild to rearing them in close environment. It was proficiently driven by a strong market demand supported by academic research and innovation in private sectors (from processing to selling). A new production section was proficiently established that assured new incomes and employment to Thai people with more than 20,000 family farms rearing insects as food and feed [10]. Implementing innovative and sustainable food production strategies, such as insect farming, may contribute to several of the SDGs, which are interconnected [6,11-14]. Insect farming could directly or indirectly contribute to several SDGs, as proposed by different Authors $[6,12,13]$. Therefore, the aim of this review was to analyse all of the SDGs one-by-one and relate them to edible insects, referring to direct-indirect effects (Figure 1). Links between SDGs were also reported in order to improve the outcomes and contributions to reach the goals.

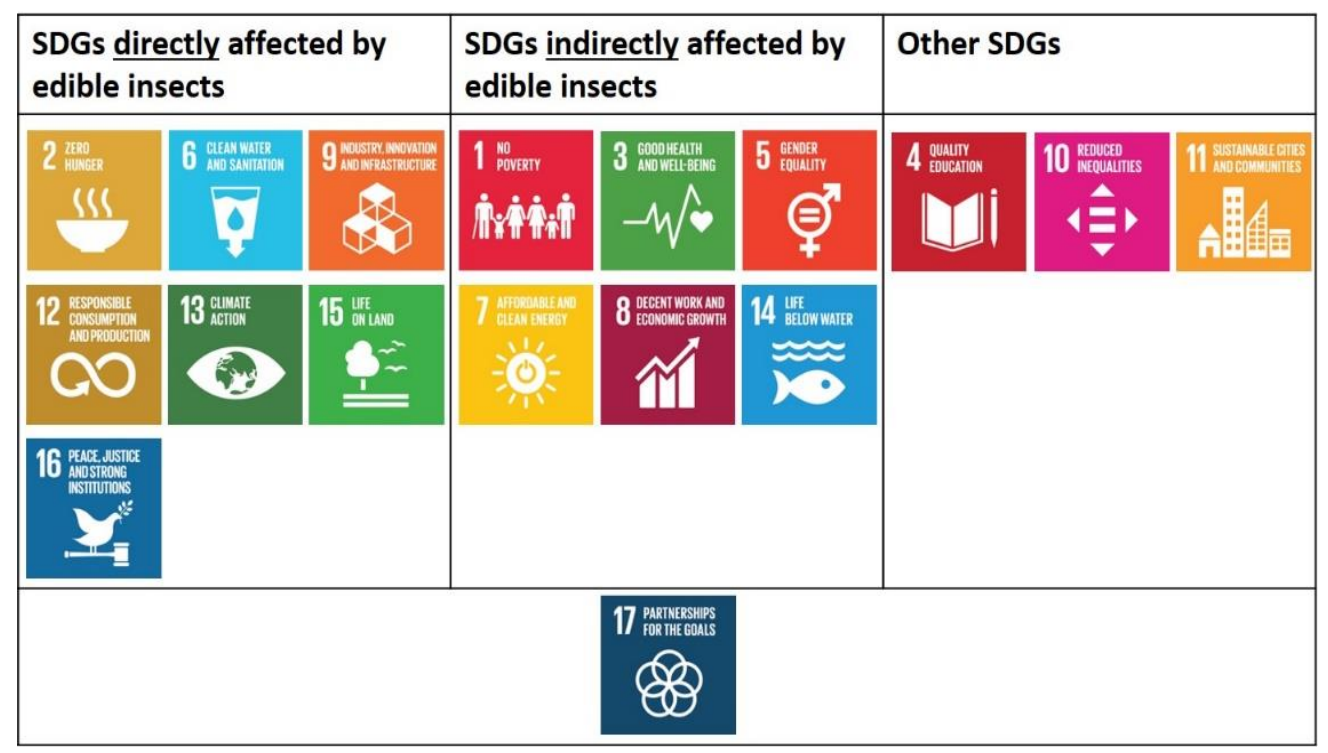

Figure 1. Interaction map between insects and sustainable development goals. 


\section{SDGs Directly Affected by Edible Insects}

2.1. SDG 2. End Hunger, Achieve Food Security, and Improved Nutrition and Promote Sustainable Agriculture

The use of insects as a major feed component could reduce the dependence on expensive and imported feed, which is a bottleneck for market entry by small-scale livestock farmers. Additionally, by culturing insects on local waste streams, any leftovers can be used as bio fertilizer, which increases farmers' independence from externally derived fertilizers [14]. Insects are highly appreciated as edible food in many parts of the world, except in most Western Countries. However, in recent years, western cultures have reconsidered entomophagy as part of a healthier and environmentally friendly diet. This has helped to push new global research, technological transfers, and international cooperation in the field $[15,16]$. In this context, there are chances for insects to become a healthy and sustainable food and feed alternative able to stimulate a proactive dialogue and operative actions between industrialized, developing, and least developed countries. In particular, insect gathering, rearing, and processing could act as important driving forces to ensure access to nutritious and sufficient food, to support economic development, fair market access, and social inclusion for disadvantaged categories. However, on a larger scale, it is important to work on the legal framework and the harmonization of a differentiated legal status of insects as food and feed across the world to facilitate the global use of this sustainable source and promote investments on both household and industrial production.

\subsection{SDG 6. Ensure Availability and Sustainable Management of Water and Sanitation for All}

Insects could contribute to improved water sanitation when they are directly reared on human-animals' faeces. Several insect groups, mainly consisting of flies, already use faeces as the main nutritional resource for their larval or adult stages. Using faeces as a substrate of insects contributes to reducing pollution, which increases the sanitation of these materials. Moreover, South African studies highlighted the potential of black soldier fly larvae in faecal sludge management on treating urine diversion dehydrating toilets $[17,18]$. In this contest, some studies reported the capability of BSF to be reared on fresh human faeces [19-22]. Similarly, animal manure derived from zootechnical productions (dairy, chicken, pig) was tested with positive results [23-28]. Insects that were reared on these substrates could be used as feed or for the production of energy (e.g., biofuel), and their faeces could also be employed as fertiliser [24,27]. Clearly, hygiene and legislation issues could arise using these waste materials as rearing substrate, mostly for insects that are intended to be used as feed (food); therefore, national laws and hygiene practices must be taken into account $[20,29]$. Some research studies even reported a positive reduction of pathogens or at least the lack of bioaccumulation of dioxins, PCBs, and PAHs, and selected pesticides, pharmaceuticals, and mycotoxins in BSF larvae [20,30-32]. Contrarily bioaccumulation might be present in BSF larvae in relation to the cadmium, lead, mercury, zinc, and arsenic up take [33,34]. Notably, insects could also eventually be used for energy production in the case of dangerous bioaccumulations, contributing to the reduction of pollution. Not least, if compared to conventional agricultural-zootechnical productions, feed-food goods that are derived from insects could contribute to decreasing the quantity of water required in the farming systems. Indeed, the low amount of water requested by insects (in some cases, even not required as furnished with moisture present in the solid feeds) could reduce water scarcity without affecting feed-food productions [5].

\subsection{SDG 9. Build Resilient Infrastructure, Promote Inclusive and Sustainable Industrialization and Foster Innovation}

Edible insects can be obtained in three ways: (I) wild harvesting; (II) semi-domestication (habitat manipulation to increase production); and, (III) farming, which can range from the single small cage scale to a large factory [35]. When only considering edible insects' human consumption (entomophagy), wild harvesting represents about $92 \%$, while semidomesticated insects only constitutes $6 \%$, according to Yen. Therefore, only $2 \%$ of edible 
insects are currently farmed. However, insects may not be available all year round in the wild due to seasonal and geographical variations. Therefore, industrial scale insect production, helped by sustainable insect breeding, farming, and processing technologies, can ease the constraints of insect availability, and lower the sale price of edible insects. It is noteworthy that, so far, farming is the most efficient way to produce insects that are intended as feed and food [36], and it could create a novel economic sector with standardized techniques on industrial scale [5]. Furthermore, farming insects in small to medium enterprise levels could contribute to producing high nutritional food in time-efficient and low technology practice [37]. Indeed, this kind of farming allows fast investment and high financial returns, due to the limited investment costs (unit/protein produced), the relatively simple management (not require in-depth training), the rapid production cycle, and the high feed conversion efficiency (with a low environmental impact if reared on side stream substrates). Low-income communities may be positively influenced via increased employment and the development of local technology [11]. Furthermore, in countries where edible insects are traditionally harvested, this practice is a source of familiar income and a socially important role, as reported by van Huis \& Oonincx [38].

\subsection{SDG 12. Ensure Sustainable Consumption and Production Patterns}

The goal of a sustainable consumption and production system is to transform energy and materials to maintain or even improve human wellbeing without negatively impacting environmental resources [39]. Food loss and waste are serious threats to the sustainability of our food systems. Roughly one-third of the global food production for human consumption (c.a. 1.3 billion tonnes per year) is lost or wasted, according to the Food and Agriculture Organisation of the United Nations (FAO) [40]. One of the SDG 12 target is to "halve the per capita global food waste at the retail and consumer levels and reduce food losses along production and supply chains, including post-harvest losses". The concept of Circular Economy (CE) can offer tools to enhance and optimise the sustainability of a food system [41]. The importance of insects in CE has been pointed out by different authors highlighting that insect farming is an advantageous choice within a CE [42,43]. In particular, using the food waste for rearing insects provides an attractive key for closing the loop of food value chain [44]. Insect farming can be easily practiced through recycling food and organic waste without having remarkable implications on productivity and quality [42]. Surely, it is useful to adopt life-cycle assessments in order to analyse the direct and indirect effects of insects in CE perspective [7,38,45]. Life-cycle assessments can have direct and indirect consequences that may result in a trade-off between the effects on land use and climate change mitigation [46]. We have to balance and carefully assess all the factors, as correctly reported by Dicke [6]. If, on one hand, waste streams could be used in insect farming for feed-food purposes, lowering land use and losses, on the other hand, we may subtract these materials to other productions, such as bio-energy production. If this energy production is overcome by fossil fuels instead of solar energy, all the effects will be lost.

\subsection{SDG 13. Take Urgent Action to Combat Climate Change and Its Impacts}

Livestock contribute drastically to the global greenhouse gas (GHG) emissions, directly and indirectly. In the publication entitled "Livestock's long shadow: environmental issues and options", the FAO directly attribute about 9 percent of total carbon dioxide emissions (not considering respiration), 37 percent of methane (rumen fermentation), and 65 percent of nitrous oxide (including feed crops) to livestock [47]. This equates to an approximate total livestock contribution of about $18 \%$ to climate change in $\mathrm{CO}_{2}$ equivalent (including pasture degradation and land use change). Insects produce very low amounts of greenhouse gases and ammonia. Oonincx et al. [48] conducted a cost-benefit analysis of five edible insects rearing systems intended as greenhouse gases production (environmental cost) and food production (benefit). Four insect species (Tenebrio molitor, Blaptica dubia, Acheta domesticus and Locusta migratoria) reported less greenhouse gas emissions than pigs and ruminants (based on $\mathrm{kg}$ of mass gain). Similarly, the ammonia levels of insect farming were lower than 
conventional livestock. It is important to highlight that farming systems could also affect GHG emissions, both in regard to insects and conventional livestock. On the other hand, insects could become a potential resilient mini-livestock production in those countries that are currently facing climate changes. The low required amount of water, the capability to be reared on side streams, and the ability to grow proficiently in hot climates could also contribute to ensuring animal production in harsh climates.

2.6. SDG 15. Protect, Restore and Promote Sustainable Use of Terrestrial Ecosystems, Sustainably Manage Forests, Combat Desertification, and Halt and Reverse Land Degradation and Halt Biodiversity Loss

Insect framing could contribute to mitigating biodiversity reduction in two ways. Firstly, insect rearing uses a small amount of land, as most of them can be reared in a close environment using horizontal and vertical farming space [49]. Moreover, insect rearing does not need direct contact with the ground and soil, and it could be done in an anthropized environment, taking advantage of already exploited locations. Thus, if insects are intended as substitution of the conventional livestock, it will induce a decrease in land use and even in restoring ecosystems. Secondly, insects could be used as feed in several other livestock production. Feed supply chain is one of the most significant environmental burdens in animal farming; reducing plant production for feed, such as soybean and corn, could contribute to increased biodiversity and combatting desertification [47]. It is noteworthy that the potential use of side stream materials as substrate for insects will also increase the circular economy, reducing total land use. Finally, increased consciousness regarding insects' features could contribute to making people more careful and respectful of wildlife animals and increase the protection of biodiversity.

2.7. SDG 16. Promote Peaceful and Inclusive Societies for Sustainable Development, Provide Access to Justice for All and Build Effective, Accountable and Inclusive Institutions at All Levels

The promotion of peaceful and inclusive societies has a strong and direct connection with the goals of food security and zero hunger. Conflicts can be the cause of food insecurity as well as a consequence when food prices increase during times of social instability and reduced food availability. Nutritional deficiencies, above all protein, emerge among disadvantaged segments of society, and smallholding farmers, on which global food production largely depends, suffer the most during times of conflict [6]. The gathering, rearing, and processing of insects offer an important tool for supporting the peace process, fighting food insecurity due to their nutritional composition, accessibility, easy and cheap rearing techniques, and the possibility to be reared on organic residual streams by-producing biofertilizer. For these reasons, the development of the production of these sustainable proteins can improve the living condition and social stability of smallholder farmers as well as vulnerable people, such as women and landless people in urban and rural areas of developing countries, which would make a valuable contribution to their economic independency and social integration $[5,12,14]$. Therefore, insects may yield a local circular economy and contribute to promoting and maintaining peaceful and inclusive societies, reducing the risks of riots and violence. However, food security is a shared responsibility, and it is important that different stakeholders are involved in the process. In this case, governments, as well as other institutions, among them universities and private companies, should be involved in national and international capacity building and networking projects, and be effective in local farmers information and training in order to develop the insect-derived food and feed sector, especially in developing countries.

\section{Links between SDGs (Directly-Indirectly Affected by Edible Insects)}

Insect farming, as a new production sector, could surely contribute to reaching several SDGs (Figure 2). 


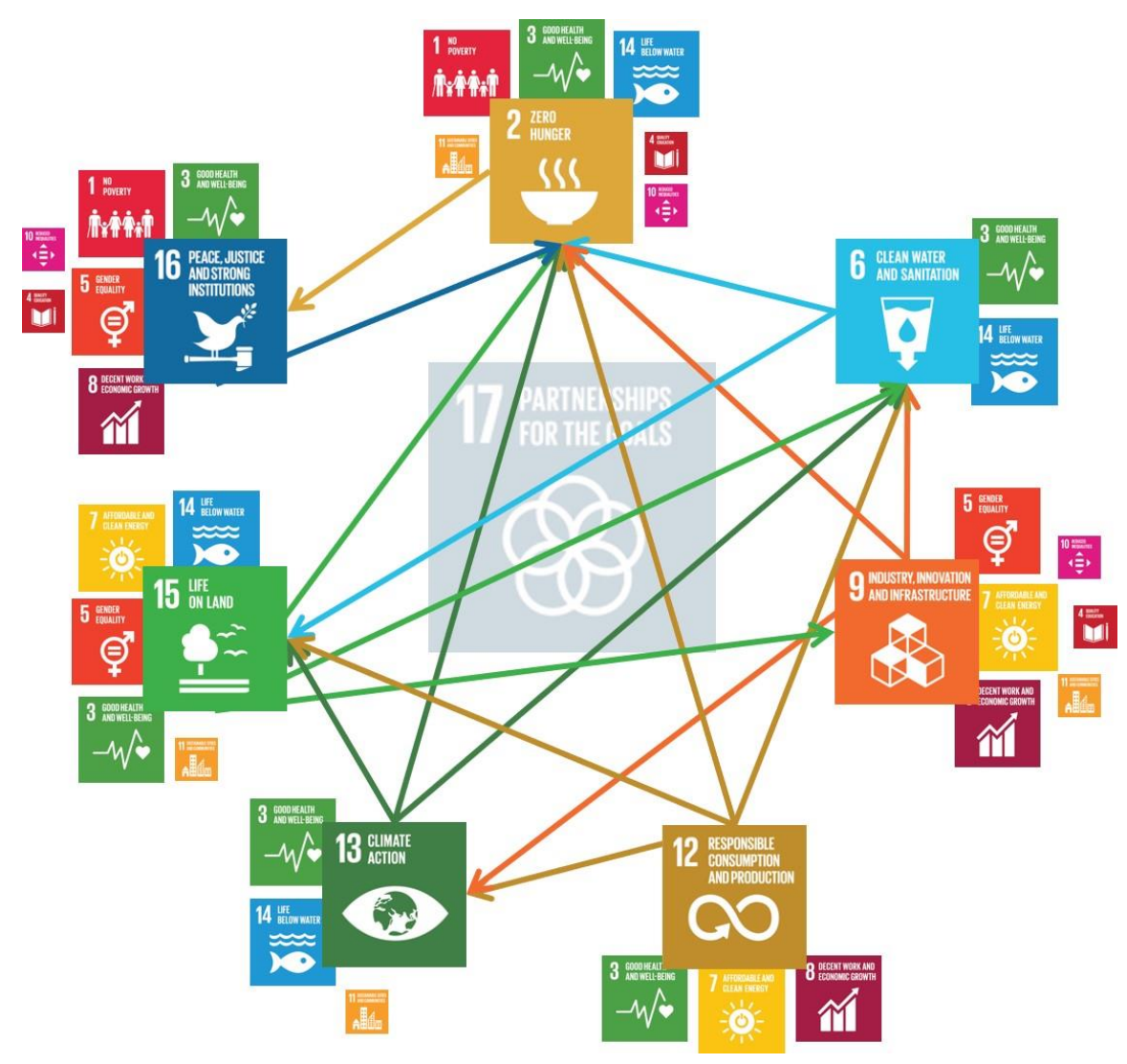

Figure 2. Links between sustainable development goals in the "edible insects' idea".

The interaction map, while not exhaustive, can help in making effective policy in the insect sector within the paradigm of the SDGs and their respective targets. A new supply chain production could corroborate markets and increase incomes, as is could also be a spark in new market niches. Insect farming, as mentioned, does not need a large initial cost, both economically and in regard to expertise. Starting a proficient insect farm could be done with small initial costs, low price materials, and does not require high personnel expertise. Therefore, this practice could also be introduced in low-income countries with a minimum level of instruction and guide. The production of insects intended to be used as feed and food could surely reduce hunger and contribute to promoting peaceful and inclusive societies, and it could also contribute to reducing the economic gaps and increasing Gross Domestic Product (GDP) (SDG 1. End poverty in all its forms everywhere; SDG 10. Reduce inequality within and among countries). An improved society, which is less influenced by financial discrepancy, will reduce vulnerability and support equal rights. These can eventuate only in terms of monetary availability, but also in gender equality (SDG 5. Achieve gender equality and empower all women and girls) and level of education (SDG 4. Quality education). The inclusion of women is a milestone to be reached as soon as possible in several countries, and it will be even more impactful in rural communities. Insect farming, as a minilivestock, is not resource intensive, and it may be more accessible to women than other farming practices that are already culturally linked as male prerogatives. This has already been demonstrated in insect wild gathering, in which women and children play major roles, both as collectors and sellers.

A healthier society with an increased economic capacity will lead to a decrease of food insecurity and susceptibility. A promotion of well-being and public health will be expected. New commercial capacity could contribute to increased incomes (SDG 8. Promote inclusive and sustainable economic growth, employment, and decent work for all), and the ability to access to better (nutritional) foods (SDG 3. Ensure healthy lives and promote well-being for all at all ages). In these topics, insect rearing could play a two-fold role, as an economic 
promoter (via new production chains) and nutritional food (compared to other animals' products). Education and training will then follow as a necessary upgrade to reaching greater societal goals and community well-being (SDG 4. Quality education).

Insect's farming could also contribute to a sustainable use of marine resources (SDG 14. Conserve and sustainably use the oceans, seas, and marine resources). Even though no aquatic insects are currently farmed, insects could contribute to the reduction of overfishing via the substitution (partially or totally) of fishmeal and fish oil in livestock feed. Indeed, a large portion of aquaculture is currently based on feed containing these two ingredients as proteins or fats, with an enormous environmental burden.

On another environmental point of view, insect farming could indirectly contribute to increasing modern and sustainable energy services (SDG 7. Ensure access to affordable, reliable, sustainable, and modern energy) playing a role as an ingredient in bio-fuel production. In this term, insect farming will not contribute more in food-feed productions, but it may still contribute to reducing waste materials (and even do not compete with the feed-food supply chains as different-not allowed-substrates could be used in this process). The increase in alternatives energy resources could contribute to the reduced use of fossil fuels, contributing to reduced air pollution (SDG 11. Make cities inclusive, safe, resilient, and sustainable), and stopping several disagreements and controversies based on the economy of fuel.

\section{Conclusions}

Feeding the rapidly growing human population in sustainable ways is essential in increasing planetary health. Furthermore, these new productions (like insects) should also participate in reducing the negative environmental impacts already established and collaborated to shift to greener productions. In particular, edible insects have the potential to confer numerous benefits to people and the environment, in accordance with several SDGs. Close collaborations among all stakeholders, government, industry, and academia are required in order to succeed. Generating knowledge sharing networks, investing in interdisciplinary research, and developing sustainable policies will be necessary to capitalize on the benefits of edible insects in the future. Legislative frameworks and cultural barriers will also play their roles, along with market strategies, but we surely have to take advance of this opportunity to actively and indirectly contribute to so many SDGs to increase the global health status. At the same time, the SDG interdependencies can be translated into policy-making requirements, and can be useful in indicating a roadmap for how research can provide orientation for policy action.

Author Contributions: All Authors contribute equally to: conceptualization, writing-original draft preparation, writing - review and editing, and funding acquisition. All authors have read and agreed to the published version of the manuscript.

Funding: The research was funded by University of Pisa, grant PRA (Progetti di Ricerca di Ateneo) number PRA_2020_12 (Produzione di Insetti come Feed e Food-PIFF).

Institutional Review Board Statement: Not applicable.

Conflicts of Interest: The authors declare no conflict of interest.

\section{References}

1. United Nations Transforming Our World: The 2030 Agenda for Sustainable Development. Available online: https://sdgs.un.org/ 2030agenda (accessed on 6 April 2021).

2. Moyer, J.D.; Hedden, S. Are we on the right path to achieve the sustainable development goals? World Dev. 2020, 127, 104749. [CrossRef]

3. Waage, J.; Yap, C.; Bell, S.; Levy, C.; Mace, G.; Pegram, T.; Unterhalter, E.; Dasandi, N.; Hudson, D.; Kock, R.; et al. Governing the UN sustainable development goals: Interactions, infrastructures, and institutions. Lancet Glob. Health 2015, 3, e251-e252. [CrossRef]

4. FAO. The State of Food Security and Nutrition in the World 2020; FAO: Rome, Italy, 2020; ISBN 978-92-5-132901-6. 
5. Van Huis, A.; Van Itterbeeck, J.; Klunder, H.; Mertens, E.; Halloran, A.; Muir, G.; Vantomme, P. Edible Insects. Future Prospects for Food and Feed Security; FAO: Rome, Italy, 2013; Volume 171, ISBN 978-92-5-107595-1.

6. Dicke, M. Insects as feed and the Sustainable Development Goals. J. Insects Food Feed 2018, 4, 147-156. [CrossRef]

7. Oonincx, D.G.A.B.; de Boer, I.J.M. Environmental impact of the production of mealworms as a protein source for humans-A Life Cycle Assessment. PLoS ONE 2012, 7, e51145. [CrossRef] [PubMed]

8. Smil, V. Worldwide transformation of diets, burdens of meat production and opportunities for novel food proteins. In Proceedings of the Enzyme and Microbial Technology; Elsevier: Amsterdam, The Netherlands, 2002; Volume 30, pp. 305-311.

9. Paoletti, M.G. Ecological Implications of Minilivestock: Potential of Insects, Rodents, Frogs and Sails; CRC Press: Boca Raton, FL, USA, 2005.

10. Hanboonsong, Y.; Jamjanya, T.; Durst, P.B. Six-Legged Livestock: Edible Insect Farming, Collecting and Marketing in Thailand; FAO: Rome, Italy, 2013; ISBN 9789251075784.

11. Chia, S.Y.; Tanga, C.M.; van Loon, J.J.; Dicke, M. Insects for sustainable animal feed: Inclusive business models involving smallholder farmers. Curr. Opin. Environ. Sustain. 2019, 41, 23-30. [CrossRef]

12. Usman, H.S.; Yusuf, A.A. Legislation and legal frame work for sustainable edible insects use in Nigeria. Int. J. Trop. Insect Sci. 2020. [CrossRef]

13. Dangles, O.; Casas, J. Ecosystem services provided by insects for achieving sustainable development goals. Ecosyst. Serv. 2019, 35, 109-115. [CrossRef]

14. Barragán-Fonseca, K.Y.; Barragán-Fonseca, K.B.; Verschoor, G.; van Loon, J.J.; Dicke, M. Insects for peace. Curr. Opin. Insect Sci. 2020, 40, 85-93. [CrossRef]

15. EFSA Panel on Nutrition Novel Foods and Food Allergens; Turck, D.; Castenmiller, J.; De Henauw, S.; Hirsch-Ernst, K.I.; Kearney, J.; Maciuk, A.; Mangelsdorf, I.; McArdle, H.J.; Naska, A.; et al. Safety of dried yellow mealworm (Tenebrio molitor larva) as a novel food pursuant to Regulation (EU) 2015/2283. EFSA J. 2021, 19. [CrossRef]

16. Mancini, S.; Moruzzo, R.; Riccioli, F.; Paci, G. European consumers' readiness to adopt insects as food. A review. Food Res. Int. 2019, 122, 661-678. [CrossRef]

17. Maleba, V.; Barnard, P.; Rodda, N. Using Black Soldier Fly Larvae to Treat Faecal Sludge from Urine Diversion Toilets; University of KwaZulu-Natal: Durban, South Africa, 2016; 18p.

18. Mutsakatira, E.; Buckley, C.A.; Mercer, S.J. Potential use of the black soldier fly larvae in faecal sludge management: A study in Durban, South Africa. In Proceedings of the 41st WEDC International Conference "Transformation towards Sustainable and resilient Wash Service", Nakuru, Kenya, 9-13 July 2018; pp. 9-13.

19. Banks, I.J.; Gibson, W.T.; Cameron, M.M. Growth rates of black soldier fly larvae fed on fresh human faeces and their implication for improving sanitation. Trop. Med. Int. Health 2014, 19, 14-22. [CrossRef] [PubMed]

20. Lalander, C.; Diener, S.; Magri, M.E.; Zurbrügg, C.; Lindström, A.; Vinnerås, B. Faecal sludge management with the larvae of the black soldier fly (Hermetia illucens)—From a hygiene aspect. Sci. Total Environ. 2013, 458-460, 312-318. [CrossRef]

21. Diener, S.; Studt Solano, N.M.; Roa Gutiérrez, F.; Zurbrügg, C.; Tockner, K. Biological Treatment of Municipal Organic Waste using Black Soldier Fly Larvae. Waste Biomass Valorization 2011, 2, 357-363. [CrossRef]

22. Nyakeri, E.M.; Ogola, H.J.O.; Ayieko, M.A.; Amimo, F.A. Valorisation of organic waste material: Growth performance of wild black soldier fly larvae (Hermetia illucens) reared on different organic wastes. J. Insects Food Feed 2017, 3, 193-202. [CrossRef]

23. Sheppard, D.C.; Newton, G.L. A value added manure management system using the black soldier fly. Bioresour. Technol. 1994, 50, 275-279. [CrossRef]

24. Li, Q.; Zheng, L.; Qiu, N.; Cai, H.; Tomberlin, J.K.; Yu, Z. Bioconversion of dairy manure by black soldier fly (Diptera: Stratiomyidae) for biodiesel and sugar production. Waste Manag. 2011, 31, 1316-1320. [CrossRef]

25. Ur Rehman, K.; Cai, M.; Xiao, X.; Zheng, L.; Wang, H.; Soomro, A.A.; Zhou, Y.; Li, W.; Yu, Z.; Zhang, J. Cellulose decomposition and larval biomass production from the co-digestion of dairy manure and chicken manure by mini-livestock (Hermetia illucens L.). J. Environ. Manag. 2017, 196, 458-465. [CrossRef] [PubMed]

26. Chen, J.; Hou, D.; Pang, W.; Nowar, E.E.; Tomberlin, J.K.; Hu, R.; Chen, H.; Xie, J.; Zhang, J.; Yu, Z.; et al. Effect of moisture content on greenhouse gas and NH3 emissions from pig manure converted by black soldier fly. Sci. Total Environ. 2019, 697, 133840. [CrossRef]

27. Xiao, X.; Mazza, L.; Yu, Y.; Cai, M.; Zheng, L.; Tomberlin, J.K.; Yu, J.; van Huis, A.; Yu, Z.; Fasulo, S.; et al. Efficient co-conversion process of chicken manure into protein feed and organic fertilizer by Hermetia illucens L. (Diptera: Stratiomyidae) larvae and functional bacteria. J. Environ. Manag. 2018, 217, 668-676. [CrossRef]

28. Rehman, K.; Ur Rehman, R.; Somroo, A.A.; Cai, M.; Zheng, L.; Xiao, X.; Ur Rehman, A.; Rehman, A.; Tomberlin, J.K.; Yu, Z.; et al. Enhanced bioconversion of dairy and chicken manure by the interaction of exogenous bacteria and black soldier fly larvae. $J$. Environ. Manag. 2019, 237, 75-83. [CrossRef] [PubMed]

29. Bosch, G.; van Zanten, H.H.E.; Zamprogna, A.; Veenenbos, M.; Meijer, N.P.; van der Fels-Klerx, H.J.; van Loon, J.J.A. Conversion of organic resources by black soldier fly larvae: Legislation, efficiency and environmental impact. J. Clean. Prod. 2019, 222, 355-363. [CrossRef]

30. Bosch, G.; Fels-Klerx, H.; Rijk, T.; Oonincx, D. Aflatoxin B1 Tolerance and Accumulation in Black Soldier Fly Larvae (Hermetia illucens) and Yellow Mealworms (Tenebrio molitor). Toxins 2017, 9, 185. [CrossRef] 
31. Charlton, A.J.; Dickinson, M.; Wakefield, M.E.; Fitches, E.; Kenis, M.; Han, R.; Zhu, F.; Kone, N.; Grant, M.; Devic, E.; et al. Exploring the chemical safety of fly larvae as a source of protein for animal feed. J. Insects Food Feed 2015, 1, 7-16. [CrossRef]

32. Purschke, B.; Scheibelberger, R.; Axmann, S.; Adler, A.; Jäger, H. Impact of substrate contamination with mycotoxins, heavy metals and pesticides on the growth performance and composition of black soldier fly larvae (Hermetia illucens) for use in the feed and food value chain. Food Addit. Contam. Part A Chem. Anal. Control. Expo. Risk Assess. 2017, 34, 1410-1420. [CrossRef] [PubMed]

33. Biancarosa, I.; Liland, N.S.; Biemans, D.; Araujo, P.; Bruckner, C.G.; Waagbø, R.; Torstensen, B.E.; Lock, E.-J.; Amlund, H. Uptake of heavy metals and arsenic in black soldier fly (Hermetia illucens) larvae grown on seaweed-enriched media. J. Sci. Food Agric. 2018, 98, 2176-2183. [CrossRef] [PubMed]

34. Van der Fels-Klerx, H.J.; Camenzuli, L.; Belluco, S.; Meijer, N.; Ricci, A. Food safety issues related to uses of insects for feeds and foods. Compr. Rev. Food Sci. Food Saf. 2018, 17, 1172-1183. [CrossRef] [PubMed]

35. Yen, A.L. Insects as food and feed in the Asia Pacific region: Current perspectives and future directions. J. Insects Food Feed 2015, 1, 33-55. [CrossRef]

36. Van Huis, A. Edible insects contributing to food security? Agric. Food Secur. 2015, 4, 1-9. [CrossRef]

37. Raheem, D.; Carrascosa, C.; Oluwole, O.B.; Nieuwland, M.; Saraiva, A.; Millán, R.; Raposo, A. Traditional consumption of and rearing edible insects in Africa, Asia and Europe. Crit. Rev. Food Sci. Nutr. 2019, 59, 2169-2188. [CrossRef]

38. Van Huis, A.; Oonincx, D.G.A.B. The environmental sustainability of insects as food and feed. A review. Agron. Sustain. Dev. 2017, 37, 43. [CrossRef]

39. Bengtsson, M.; Alfredsson, E.; Cohen, M.; Lorek, S.; Schroeder, P. Transforming systems of consumption and production for achieving the sustainable development goals: Moving beyond efficiency. Sustain. Sci. 2018, 13, 1533-1547. [CrossRef] [PubMed]

40. Gustavsson, J.; Cederberg, C.; Sonesson, U.; Emanuelsson, A. The Methodology of the FAO Study: “Global Food Losses and Food Waste-Extent, Causes and Prevention"-FAO, 2011; SIK Report; FAO: Rome, Italy, 2013; ISBN 9789172903234.

41. Jurgilevich, A.; Birge, T.; Kentala-Lehtonen, J.; Korhonen-Kurki, K.; Pietikäinen, J.; Saikku, L.; Schösler, H. Transition towards circular economy in the food system. Sustainability 2016, 8, 69. [CrossRef]

42. Madau, F.A.; Arru, B.; Furesi, R.; Pulina, P. Insect farming for feed and food production from a circular business model perspective. Sustainability 2020, 12, 5418. [CrossRef]

43. Derler, H.; Lienhard, A.; Berner, S.; Grasser, M.; Posch, A.; Rehorska, R. Use them for what they are good at: Mealworms in circular food systems. Insects 2021, 12, 40. [CrossRef]

44. Ojha, S.; Bußler, S.; Schlüter, O.K. Food waste valorisation and circular economy concepts in insect production and processing. Waste Manag. 2020, 118, 600-609. [CrossRef]

45. Halloran, A.; Bruun, S. Life cycle assessment of edible insects for food protein: A review. Agron. Sustain. Dev. 2016, 36, 1-13. [CrossRef]

46. Van Zanten, H.H.E.; Mollenhorst, H.; Oonincx, D.G.A.B.; Bikker, P.; Meerburg, B.G.; De Boer, I.J.M. From environmental nuisance to environmental opportunity: Housefly larvae convert waste to livestock feed. J. Clean. Prod. 2015, 102, 362-369. [CrossRef]

47. Steinfeld, H.; Gerber, P.; Wassenaar, T.; Castel, V.; Rosales, M.; de Haan, C. Livestock's Long Shadow: Environmental Issues and Options; FAO: Rome, Italy, 2006.

48. Oonincx, D.G.A.B.; van Itterbeeck, J.; Heetkamp, M.J.W.; van den Brand, H.; van Loon, J.J.A.; van Huis, A. An exploration on greenhouse gas and ammonia production by insect species suitable for animal or human consumption. PLoS ONE 2010, 5, e14445. [CrossRef]

49. Cortes Ortiz, J.A.; Ruiz, A.T.; Morales-Ramos, J.A.; Thomas, M.; Rojas, M.G.; Tomberlin, J.K.; Yi, L.; Han, R.; Giroud, L.; Jullien, R.L. Insect Mass Production Technologies. In Insects as Sustainable Food Ingredients; Elsevier: Amsterdam, The Netherlands, 2016; pp. 153-201. 